\title{
KEPUASAN MAHASISWA TERHADAP IMPLEMENTASI E-CRM PADA BINUS UNIVERSITY
}

\author{
Meyliana; Henry Antonius E.W.; Stephen W. Santoso \\ Information Systems Department, School of Information Systems, Binus University \\ Jln. K.H. Syahdan No. 9, Palmerah, Jakarta Barat 11480 \\ meyliana@binus.edu; haew@binus.edu; ssantoso@binus.edu
}

\begin{abstract}
ABSTRAK
Industri pendidikan merupakan perusahaan jasa yang tidak sama dengan karakteristik perusahaan jasa pada umumnya karena memiliki keunikan tersendiri. Hal ini yang menyebabkan penerapan e-CRM dalam institusi pendidikan berbeda dengan perusahaan jasa lainnya. Metode penelitian menggunakan variabel PrePurchase, At-Purchase, Post-Purchase, e-Trust, e-Satisfaction dan e-Loyalty di mana hipotesisnya diuji berdasarkan análisis korelasi dan análisis regresi serta menggunakan IPA (Importance Performance Analysis) untuk melihat hal-hal yang perlu ditingkatkan dengan menghitung gap analisisnya. Dari hasil pengujian didapat bahwa berdasarkan análisis korelasi, semua hipotesis H1 (ada hubungan) diterima dan berdasarkan análisis regresi, semua hipotesis H1 (berpengaruh) diterima. Berdasarkan IPA, baik untuk peningkatan prioritas pertama dan kedua, semua variabel perlu ditingkatkan.
\end{abstract}

Kata kunci: e-CRM, Pre-Purchase, At-Purchase, Post-Purchase, e-Trust, e-Satisfaction, e-Loyalty

\begin{abstract}
Education industry is a service enterprise that has its unique characteristics. Thus, the implementation of e-CRM in education institutions and other service companies is different. The research methodology uses variables Pre-Purchase, At-Purchase, Post-Purchase, e-Trust, e-Satisfaction and e-Loyalty, where the hypothesis was tested by correlation analysis and regression analysis. Besides, it also uses IPA (Importance Performance Analysis) to identify factors to be improved by calculating the gap analysis. The test results obtained show that based on the correlation analysis, all the H1hypotheses (has relationship) are accepted and based on the regression analysis, all the hypotheses $\mathrm{H1}$ (has effects) is accepted. Under the IPA, for both increases in the first priority and second priority, all the variables need to be improved.
\end{abstract}

Keywords: e-CRM, Pre-Purchase, At-Purchase, Post-Purchase, e-Trust, e-Satisfaction, e-Loyalty 


\section{PENDAHULUAN}

Persaingan bisnis yang semakin ketat telah mengubah posisi pelanggan di mata perusahaan. Pelanggan sekarang telah menjadi fokus yang sangat penting bagi keberlanjutan suatu perusahaaan. Hal ini menyebabkan posisi pelanggan telah menjadi faktor penentu dalam keberhasilan strategi suatu perusahaan. Konsep inilah yang disebut dengan Customer Engagement, bukan hanya sekedar Customer Relationship (Greenberg, 2010).

Customer Engagement merupakan fokus dalam implementasi Customer Relationship Management (CRM). CRM memiliki tiga karakteristik utama yaitu pemasaran (marketing), penjualan (sales), dan layanan (service). Definisi CRM adalah filosofi dan strategi bisnis yang didukung oleh sistem dan teknologi yang didesain untuk meningkatkan interaksi manusia dalam lingkungan bisnis. Seiring semakin meluasnya penggunaan social media yang didalamnya terdapat konsep social networking, maka konsep CRM pun mulai bergeser menjadi Social CRM. Definisi Social CRM adalah strategi bisnis yang didukung oleh teknologi, peraturan bisnis, proses, dan karakteristik sosial yang didesain untuk mengikutsertakan pelanggan dalam interaksi yang terkolaborasi untuk memberikan nilai yang saling menguntungkan dalam lingkungan bisnis yang jujur dan transparan sebagai respon perusahaan terhadap kepemilikan pelanggan atas interaksi tersebut (Greenberg, 2010).

CRM sering juga disebut dengan e-CRM karena menggunakan teknologi dalam implementasinya. Definisi e-CRM adalah penggunaan teknologi komunikasi digital untuk memaksimalkan penjualan kepada pelanggan dan memacu penggunaan jasa online yang berkelanjutan (Chaffey, 2009).

Institusi pendidikan yang dipilih dalam penelitian ini adalah BINUS University dan e-CRM yang akan dibahas adalah penerapannya pada website BINUS (www.binus.ac.id) dan LMS BINUSMaya (binusmaya.binus.ac.id). Tujuan penelitian ini untuk mengetahui tingkat pemenuhan harapan user dibandingkan dengan kepuasannya dan memberikan rekomendasi dari faktor-faktor yang mempengaruhi implementasi e-CRM. Sedangkan manfaat yang didapat dengan penelitian ini adalah memberikan review implemantasi e-CRM yang telah dilakukan oleh BINUS University dan memberikan informasi dan hasil temuan serta hubungan antara faktor-faktor dalam implementasi eCRM dengan kepuasan dan loyalitas pelanggan.

\section{METODE}

Metodologi penelitian yang digunakan dapat dilihat pada Gambar 1 berikut.

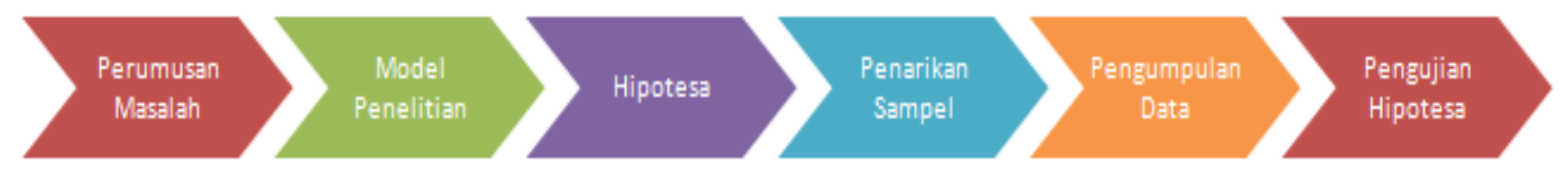

Gambar 1. Metodologi penelitian.

Perumusan masalahnya adalah apakah Pre-purchase, At-purchase, Post-purchase dan eTrust memiliki hubungan dan dampak yang signifikan dengan $e$-Satisfaction, apakah $e$-Trust dan $e$ Satisfaction memiliki hubungan dan dampak yang signifikan dengan e-Loyalty, dan hal-hal apa saja yang belum mepenuhi kebutuhan user dan yang harus ditingkatkan dalam e-CRM BINUS University. Model peneltian dapat dilihat pada Gambar 2 berikut. 


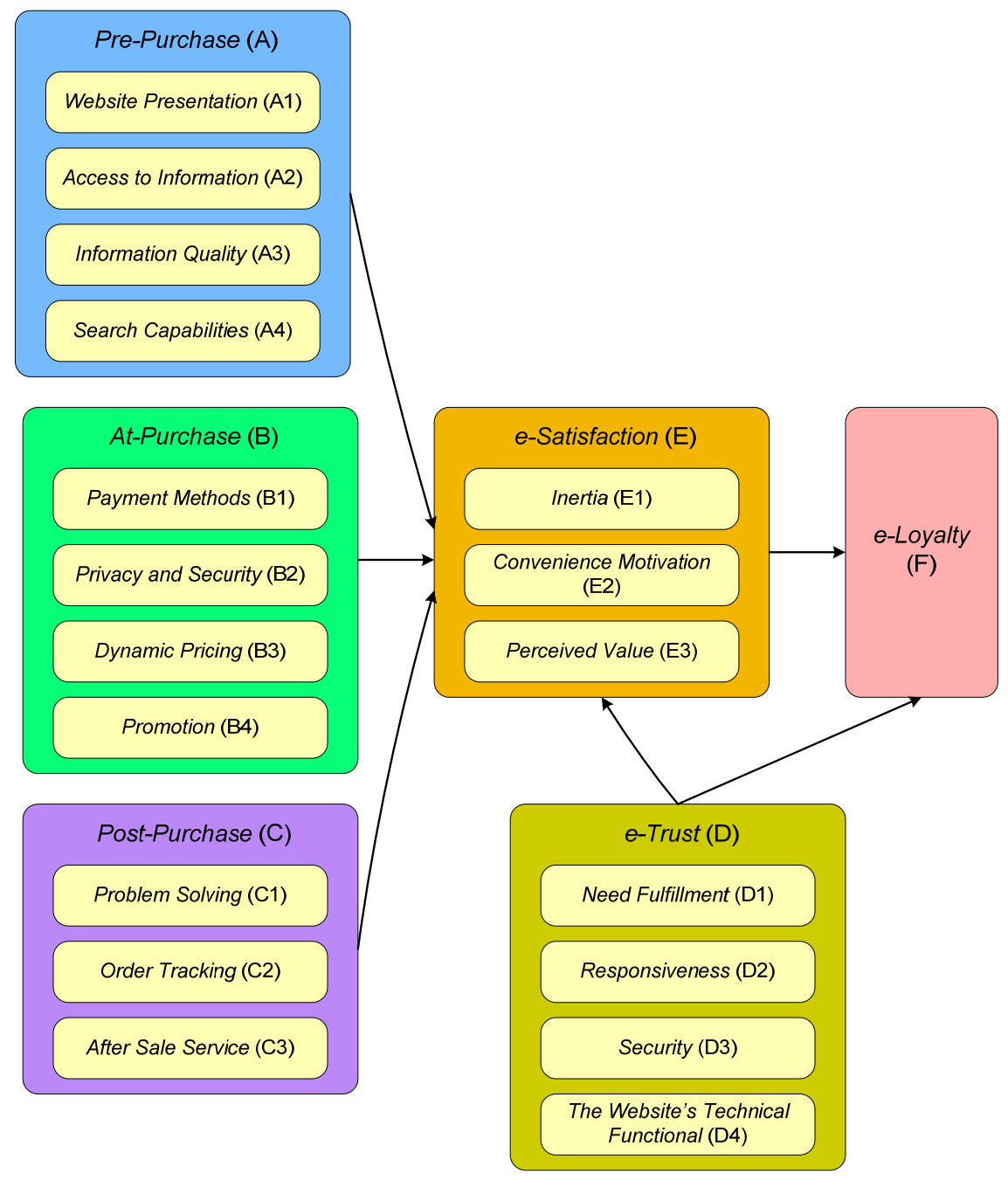

Gambar 2. Model penelitian.

Berdasarkan Alhaiou, Ali, dan Irani (2009) terdapat beberapa variabel-variabel yang telah teruji validitas, reliabilitas, korelasi dan regresi-nya, sehingga variabel tersebut dapat digunakan kembali pada penelitian ini. Variabel-variabel yang digunakan pada penelitian ini berguna untuk mengetahui apakah ada tidaknya hubungan (korelasi) dan pengaruh (regresi) antara satu variabel terhadap variabel lainnya khususnya terhadap kedua website BINUS University ( www.binus.ac.id dan binusmaya.binus.ac.id). Adapun detil penjelasan tiap variabel dapat dilihat pada tabel 1 .

Tabel 1

Penjelasan Tiap Variabel

\begin{tabular}{cll}
\hline Nama Variabel & \multicolumn{1}{c}{$\begin{array}{c}\text { Nama } \\
\text { Sub Variabel }\end{array}$} & \multicolumn{1}{c}{ Penjelasan } \\
\hline Pre-Purchase (A) & Website Presentation (A1) & $\begin{array}{l}\text { Hal ini mengacu pada tampilan, gambar, dan informasi yang } \\
\text { dimuat dalam website }\end{array}$ \\
\cline { 2 - 4 } & Access to Information (A2) & $\begin{array}{l}\text { Seberapa mudah pelanggan mencari informasi dari produk, } \\
\text { harga, dan pelayanan }\end{array}$ \\
\cline { 2 - 4 } & Information Quality (A3) & $\begin{array}{l}\text { Hal ini mengacu pada ketepatan, isi, dan informasi terkini } \\
\text { dalam website }\end{array}$ \\
\hline
\end{tabular}




\begin{tabular}{|c|c|c|}
\hline & Search Capabilities (A4) & $\begin{array}{l}\text { Search engine yang memungkinkan pelanggan untuk } \\
\text { menentukan beberapa kriteria sehingga memperoleh } \\
\text { informasi yang diinginkan secara cepat }\end{array}$ \\
\hline \multirow[t]{4}{*}{ At-Purchase (B) } & Payment Methods (B1) & $\begin{array}{l}\text { Memungkinkan pelanggan untuk memilih metode untuk } \\
\text { pembayaran. Misalkan: credit card, cash pada saat delivery, } \\
\text { cek }\end{array}$ \\
\hline & Privacy and Security (B2) & $\begin{array}{l}\text { Kemampuan sebuah website untuk menjamin keamanan data } \\
\text { pelanggan selama melakukan transaksi }\end{array}$ \\
\hline & Dynamic Pricing (B3) & $\begin{array}{l}\text { Penentuan harga berdasarkan karakteristik status pelanggan } \\
\text { dan order. Contohnya: kuantitas, product mix }\end{array}$ \\
\hline & Promotion (B4) & $\begin{array}{l}\text { Melakukan penawaran promosi kepada pelanggan selama } \\
\text { proses pembelian }\end{array}$ \\
\hline \multirow[t]{3}{*}{ Post-Purchase (C) } & Problem Solving $(\mathrm{C} 1)$ & $\begin{array}{l}\text { Hal ini dapat berbentuk online manual, FAQ, experts system, } \\
\text { web agents }\end{array}$ \\
\hline & Order Tracking (C2) & $\begin{array}{l}\text { Sebuah kemampuan yang digunakan untuk melacak apakah } \\
\text { barang atau informasi telah sampai / terkirim dan melakukan } \\
\text { follow up pertahap }\end{array}$ \\
\hline & After Sale Service (C3) & $\begin{array}{l}\text { Customer support dapat berupa pemberian garansi, } \\
\text { kebijakan retur, dll }\end{array}$ \\
\hline \multirow[t]{4}{*}{$e$-Trust (D) } & Need Fulfillment (D1) & Memberikan personal webiste \\
\hline & Responsiveness (D2) & Memberikan respon terhadap pelanggan yang cepat \\
\hline & Security (D3) & $\begin{array}{l}\text { Bagaimana pelanggan merasa aman dan nyaman dalam } \\
\text { menggunakan website }\end{array}$ \\
\hline & $\begin{array}{l}\text { The Website's Technical } \\
\text { Functional (D4) }\end{array}$ & Bagaimana pelanggan dapat menggunakan website tersebut \\
\hline \multirow[t]{3}{*}{ e-Satisfaction (E) } & Inertia (E1) & Pelanggan melakukan bookmark terhadap website tersebut \\
\hline & $\begin{array}{l}\text { Convenience Motivation } \\
\text { (E2) }\end{array}$ & $\begin{array}{l}\text { Memberikan layanan kepada customer agar merasa nyaman } \\
\text { dan termotivasi untuk melakukan pembelian }\end{array}$ \\
\hline & Perceived Value (E3) & $\begin{array}{l}\text { Memberikan value yang terbaik untuk customer sesuai } \\
\text { dengan harga yang telah mereka keluarkan }\end{array}$ \\
\hline e-Loyalty (F) & & $\begin{array}{l}\text { Melakukan pembelian yang berulang - ulang dan terus } \\
\text { menerus bahkan akan tetap membeli walaupun dengan harga } \\
\text { yang premium }\end{array}$ \\
\hline
\end{tabular}

Hipotesis disusun berdasarkan analisis korelasi dan analisis regresi berganda menjadi 28 hipotesis, yaitu:

Hipotesis 1:

H0: Pre-Purchase tidak berhubungan dengan Inertia.

H1: Pre-Purchase berhubungan dengan Inertia.

Hipotesis 2:

H0: Pre-Purchase tidak berhubungan dengan Convenience Motivation.

H1: Pre-Purchase berhubungan dengan Convenience Motivation.

Hipotesis 3:

H0: Pre-Purchase tidak berhubungan dengan Perceived Value.

H1: Pre-Purchase berhubungan dengan Perceived Value.

Hipotesis 4:

H0: At-Purchase tidak berhubungan dengan Inertia.

H1: At-Purchase berhubungan dengan Inertia.

Hipotesis 5:

H0: At-Purchase tidak berhubungan dengan Convenience Motivation. 
H1: At-Purchase berhubungan dengan Convenience Motivation.

Hipotesis 6:

H0: At-Purchase tidak berhubungan dengan Perceived Value.

H1: At-Purchase berhubungan dengan terhadap Perceived Value.

Hipotesis 7:

H0: Post-Purchase tidak berhubungan dengan Inertia.

H1: Post-Purchase berhubungan dengan Inertia.

Hipotesis 8:

H0: Post-Purchase tidak berhubungan dengan Convenience Motivation.

H1: Post-Purchase berhubungan dengan Convenience Motivation.

Hipotesis 9:

H0: Post-Purchase tidak berhubungan dengan Perceived Value.

H1: Post-Purchase berhubungan dengan Perceived Value.

Hipotesis 10:

H0: e-Trust tidak berhubungan dengan Inertia.

H1: e-Trust berhubungan dengan Inertia.

Hipotesis 11:

H0: e-Trust tidak berhubungan dengan Convenience Motivation.

H1: e-Trust berhubungan dengan Convenience Motivation.

Hipotesis 12:

H0: e-Trust tidak berhubungan dengan Perceived Value.

H1: e-Trust berhubungan dengan Perceived Value.

Hipotesis 13:

H0: $e$-Trust tidak berhubungan dengan $e$-Loyalty.

$\mathrm{H} 1: e$-Trust berhubungan dengan $e$-Loyalty.

Hipotesis 14:

H0: e-Satisfaction tidak berhubungan dengan e-Loyalty.

$\mathrm{H} 1$ : e-Satisfaction berhubungan dengan $e$-Loyalty.

Hipotesis 15:

H0: Pre-Purchase tidak memiliki pengaruh terhadap Inertia.

H1: Pre-Purchase memiliki pengaruh terhadap Inertia.

Hipotesis 16:

H0: Pre-Purchase tidak memiliki pengaruh terhadap Convenience Motivation.

H1: Pre-Purchase memiliki pengaruh terhadap Convenience Motivation.

Hipotesis 17:

H0: Pre-Purchase tidak memiliki pengaruh terhadap Perceived Value.

H1: Pre-Purchase memiliki pengaruh terhadap Perceived Value.

Hipotesis 18:

H0: At-Purchase tidak memiliki pengaruh terhadap Inertia.

H1: At-Purchase memiliki pengaruh terhadap Inertia. 
Hipotesis 19:

H0: At-Purchase tidak memiliki pengaruh terhadap Convenience Motivation.

H1: At-Purchase memiliki pengaruh terhadap Convenience Motivation.

Hipotesis 20:

H0: At-Purchase tidak memiliki pengaruh terhadap Perceived Value.

H1: At-Purchase memiliki pengaruh terhadap Perceived Value.

Hipotesis 21:

H0: Post-Purchase tidak memiliki pengaruh terhadap Inertia.

H1: Post-Purchase memiliki pengaruh terhadap Inertia.

Hipotesis 22:

H0: Post-Purchase tidak memiliki pengaruh terhadap Convenience Motivation.

H1: Post-Purchase memiliki pengaruh terhadap Convenience Motivation.

Hipotesis 23:

H0: Post-Purchase tidak memiliki pengaruh terhadap Perceived Value.

H1: Post-Purchase memiliki pengaruh terhadap Perceived Value.

Hipotesis 24:

H0: e-Trust tidak memiliki pengaruh terhadap Inertia.

H1: $e$-Trust memiliki pengaruh terhadap Inertia.

Hipotesis 25:

H0: e-Trust tidak memiliki pengaruh terhadap Convenience Motivation.

H1: e-Trust memiliki pengaruh terhadap Convenience Motivation.

Hipotesis 26:

H0: e-Trust tidak memiliki pengaruh terhadap Perceived Value.

H1: e-Trust memiliki pengaruh terhadap Perceived Value.

Hipotesis 27:

H0: $e$-Trust tidak memiliki pengaruh terhadap $e$-Loyalty.

$\mathrm{H} 1$ : e-Trust memiliki pengaruh terhadap e-Loyalty.

Hipotesis 28:

H0: e-Satisfaction tidak memiliki pengaruh terhadap e-Loyalty.

H1: e-Satisfaction memiliki pengaruh terhadap e-Loyalty.

Analisis korelasi dilakukan untuk melihat apakah ada hubungan antara varibel bebas dan variabel terikat dan korelasi ini dilakukan menggunakan teknik korelasi Product Moment, yang rumusnya data dijelaskan sebagai berikut (Sugiyono, 2008).

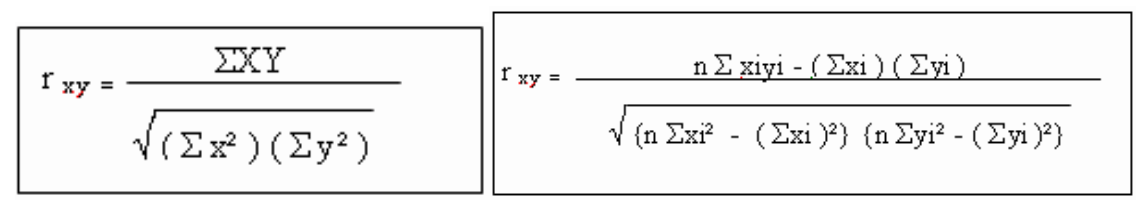

keterangan:

$R=$ Koefisien korelasi 
$x i=$ Jumlah variabel $\mathrm{X}$

$y i=$ Jumlah variabel $\mathrm{Y}$

$n=$ Jumlah Sampel

Sedangkan analisis regresi berganda dilakukan untuk menguji apakah variabel bebas memiki pengaruh atau dampak terhadap variabel terikat dan berapa besar pengaruh tersebut. Bentuk persamaan regresi: $\mathrm{Y}^{\prime}=\mathrm{a}+\mathrm{bX}$, di mana

$\mathrm{Y}^{\prime}=$ subyek dalam variabel dependen yang diprediksikan

$\mathrm{a}=$ harga $\mathrm{Y}$ bila $\mathrm{X}=0$ (harga konstan)

$\mathrm{b}=$ angka arah atau koefisien regresi, yang menunjukkan angka

$\mathrm{X}=$ subyek pada variabel independen yang mempunyai nilai tertentu.

Peningkatan ataupun penurunan variabel terikat yang didasarkan pada variabel bebas. Bila $b(+)$, naik. Dan bila (-), akan terjadi penurunan (Sugiyono, 2008).

Unuk melihat hal-hal yang harus ditingkatkan pada website BINUS dan BINUSMaya, akan digunakan gap analisis dengan menggunakan metode IPA (Importance Performance Analysis). Metode IPA pertama kali diperkenalkan oleh Martilla dan James pada tahun 1977 dengan tujuan untuk mengukur hubungan antara persepsi konsumen dan prioritas peningkatan kualitas produk/ jasa yang dikenal pula sebagai quadrant analysis (Brandt, 2000 dan Latu \& Everett, 2000). IPA telah diterima secara umum dan dipergunakan pada berbagai bidang kajian karena kemudahan untuk diterapkan dan tampilan hasil analisis yang memudahkan usulan perbaikan kinerja (Martinez, 2003). IPA mempunyai fungsi utama untuk menampilkan informasi berkaitan dengan faktor-faktor pelayanan yang menurut konsumen sangat mempengaruhi kepuasan dan loyalitas mereka, dan faktor-faktor pelayanan yang menurut konsumen perlu ditingkatkan karena kondisi saat ini belum memuaskan. IPA menggabungkan pengukuran faktor tingkat kepentingan dan tingkat kepuasan dalam grafik dua dimensi yang memudahkan penjelasan data dan mendapatkan usulan praktis. Interpretasi grafik IPA sangat mudah, di mana grafik IPA dibagi menjadi empat buah kuadran berdasarkan hasil pengukuran sebagaimana terlihat pada Gambar 3.

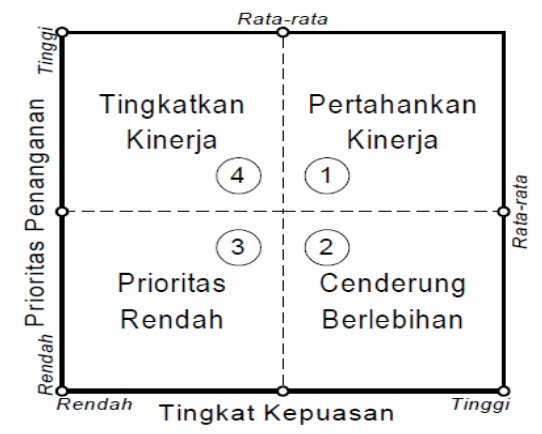

Gambar 3. Pembagian kuadran importance performance analysis.

Berikut penjelasan untuk masing-masing kuadran (Brandt, 2000): Kuadran Pertama, "Pertahankan Kinerja" (high importance \& high performance) - faktor-faktor yang terletak pada kuadran ini dianggap sebagai faktor penunjang bagi kepuasan konsumen sehingga pihak manajemen berkewajiban memastikan bahwa kinerja institusi yang dikelolanya dapat terus mempertahankan prestasi yang telah dicapai.

Kuadran Kedua, "Cenderung Berlebihan" (low importance \& high performance) - faktorfaktor yang terletak pada kuadran ini dianggap tidak terlalu penting sehingga pihak manajemen perlu mengalokasikan sumber daya yang terkait dengan faktor-faktor tersebut kepada faktor-faktor lain yang mempunyai prioritas penanganan lebih tinggi yang masih membutuhkan peningkatan, semisal dikuadran keempat. Kuadran Ketiga, "Prioritas Rendah" (low importance \& low performance) - 
faktor-faktor yang terletak pada kuadran ini mempunyai tingkat kepuasan yang rendah dan sekaligus dianggap tidak terlalu penting bagi konsumen, sehingga pihak manajemen tidak perlu memprioritaskan atau terlalu memberikan perhatian pada faktor-faktor tersebut. Kuadran Keempat, "Tingkatkan Kinerja" (high importance \& low performance) - faktor-faktor yang terletak pada kuadran ini dianggap sebagai faktor yang sangat penting oleh konsumen namun kondisi pada saat ini belum memuaskan sehingga pihak manajemen berkewajiban mengalokasikan sumber daya yang memadai untuk meningkatkan kinerja berbagai faktor tersebut. Faktor-faktor yang terletak pada kuadran ini merupakan prioritas untuk ditingkatkan.

Ada dua macam metode untuk menampilkan data IPA, yaitu: pertama, menempatkan garis perpotongan kuadran pada nilai rata-rata pada sumbu tingkat kepuasan dan sumbu prioritas penangganan dengan tujuan untuk mengetahui secara umum penyebaran data terletak pada kuadran berapa. Pada bagian ini digunakan nilai rata-rata pada skala pengukuran tingkat kepuasan dan prioritas penanganan sebagai garis pemisah antar kuadran. Kedua, menempatkan garis perpotongan kuadran pada nilai rata-rata hasil pengamatan pada sumbu tingkat kepuasan dan sumbu prioritas penangganan dengan tujuan untuk mengetahui secara spesifik masing-masing faktor terletak pada kuadran berapa. Pada bagian ini digunakan nilai rata-rata hasil pengukuran tingkat kepuasan dan prioritas penanganan sebagai garis pemisah antar kuadran (Martinez, 2003). Berikut prosedur berkaitan dengan penggunaan metode IPA: (1) penentuan faktor-faktor yang akan dianalisis; (2) melakukan survei melalui penyebaran kuesioner; (3) menghitung nilai rata-rata tingkat kepuasan dan prioritas penanganan; (4) membuat grafik IPA; (5) melakukan evaluasi terhadap faktor sesuai dengan kuadran masing-masing.

Metode transformasi yang digunakan yakni method of successive interval (Hays, 1976). Metode tersebut digunakan untuk melakukan transformasi data ordinal menjadi data interval. Pada umumnya jawaban responden yang diukur dengan menggunakan skala likert (Lykert scale) diadakan scoring yakni pemberian nilai numerikal 1, 2, 3, 4, dan 5. Setiap skor yang diperoleh akan memiliki tingkat pengukuran ordinal. Nilai numerikal tersebut dianggap sebagai objek dan selanjutnya melalui proses transformasi ditempatkan ke dalam interval. Langkah-langkahnya adalah sebagai berikut: (1) untuk setiap pertanyaan, hitung frekuensi jawaban setiap kategori (pilihan jawaban); (2) berdasarkan frekuensi setiap kategori dihitung proporsinya; (3) dari proporsi yang diperoleh, hitung proporsi kumulatif untuk setiap kategori; (4) tentukan pula nilai batas Z untuk setiap kategori; (5) hitung scale value (interval rata-rata) untuk setiap kategori melalui persamaan berikut:

$$
\text { Seale - } \frac{\text { Kepadatan batas bawah - Kepadatan batas atas }}{\text { daerah di bawah batas atas - daerah di bawah batas bawah }}
$$

(6) hitung score (nilai hasil transformasi) untuk setiap kategori melalui persamaan:

$$
\text { score }=\text { scaleValue }+\mid \text { scaleValuemin } \mid+1
$$

Populasi dalam penelitian ini adalah semua mahasiswa aktif jurusan Sistem Informasi BINUS University yaitu BINUSIAN 2011, 2012, 2013, dan 2014 yang berjumlah 4.467 mahasiswa. Jumlah detilnya dapat dilihat pada Tabel 2.

Tabel 2

Jumlah Mahasiswa Aktif Jurusan Sistem Informasi

\begin{tabular}{cc}
\hline BINUSIAN & Jumlah Mahasiswa Aktif \\
\hline 2011 & 989 \\
\hline 2012 & 1.137 \\
\hline 2013 & 1.112 \\
\hline 2014 & 1.229 \\
\hline Total & $\mathbf{4 . 4 6 7}$ \\
\hline
\end{tabular}


Untuk menghitung jumlah sampel dari populasi tersebut digunakan rumus Isaac dan Michael. Dari tabel perhitungan sampel (Sugiyono, 2008) didapatkan bahwa apabila jumlah populasi 4467 mahasiswa maka jumlah sampelnya adalah 323 mahasiswa. Dengan taraf kesalahan 5\% didapat hasil jumlah kuesioner yang harus dikumpulkan disesuaikan dengan jumlah populasi masing-masing angkatan. Rinciannya dapat dilihat pada Tabel 3 di bawah ini.

Tabel 3

Responden Kuesioner Valid

\begin{tabular}{cccc}
\hline Responden & Jumlah Responden & Kuesioner yang Disebarkan & Kuesioner yang Terkumpul \\
\hline Binusian 2011 & 989 & 110 & 105 \\
\hline Binusian 2012 & 1.137 & 90 & 83 \\
\hline Binusian 2013 & 1.112 & 60 & 57 \\
\hline Binusian 2014 & 1.229 & 90 & 78 \\
\hline Total & $\mathbf{4 . 4 6 7}$ & $\mathbf{3 5 0}$ & $\mathbf{3 2 3}$ \\
\hline
\end{tabular}

Teknik pengumpulan data yang digunakan adalah melakukan studi lapangan secara langsung dan sampling membagikan kuesioner kepada pengguna website BINUS dan BINUSMaya. Data yang terkumpul diukur menggunakan statistical analysis tools seperti software SPSS 17.0 atau Microsoft Excel dan metode yang digunakan ialah multiple regression dan correlation model. Kuesioner yang disebaran kepada responden berisikan pertanyaan-pertanyaan yang berkaitan dengan variabel PrePurchase (A), At-Purchase (B), Post-Purchase (C), e-Trust (D), e-Satisfaction (E) dan e-Loyalty (F). Berikut daftar dari pertanyaan yang diajukan melalui kuesioner kepuasan pengguna terhadap website BINUS dan BINUSMaya (Meyliana et al., 2011), yang dapat dilihat pada Tabel 4 berikut ini.

Secara sederhana uji validitas dan reliabilitas dilakukan dengan membandingkan nilai korelasi ( $r$ hitung) dan Cronbach's Alpha yang dihasilkan dengan menggunakan bantuan software SPSS Statistic 17.0, dengan nilai dari $r$ tabel. Secara umum, ketentuannya adalah jika nilai korelasi $(r$ hitung) lebih besar dari $r$ tabel maka pertanyaan tersebut dikatakan valid. Demikian juga jika Cronbach's Alpha lebih besar daripada $r$ tabel maka variabel tersebut dapat dipercaya. Karena banyaknya pertanyaan dan jumlah variabel yang diuji serta melibatkan dua sudut pandang penilaian sekaligus (derajat kepentingan dan kenyaataan), skenario pengujian validitas dan reliabilitas dibagi ke dalam empat bagian, yaitu: uji validitas untuk derajat kepentingan, uji validitas untuk derajat kepuasan, uji reliabilitas untuk derajat kepentingan, dan uji reliabilitas untuk derajat kepuasan (Tabel 5). Untuk $n$ sebanyak 30 dan $\alpha 5 \%$, nilai $r$ tabel adalah 0,361. Dari hasil uji korelasi dengan metode Pearson, semua nilai korelasi ( $r$ hitung atau Pearson's Correlation) lebih besar dari $r$ tabel (0.098) dan nilai dari Sig (2-tailed) di bawah 0.05 maka H0 ditolak dan H1 diterima untuk hipotesis 1 sampai hipotesis 14. Hasil lengkap dapat dilihat pada Tabel 6. Dari hasil pengujian regresi didapat bahwa $r$ lebih besar dari ( $r$ tabel: 0.098) dan menunjukkan angka positif serta nilai Sig 0.000 (lebih kecil dari 0.05) sehingga $\mathrm{HO}$ ditolak dan $\mathrm{H1}$ diterima. Besarnya dampak/pengaruh variabel A, B, C, D terhadap variabel $\mathrm{E}$, variabel $\mathrm{D}$ terhadap variabel $\mathrm{F}$ dan variabel $\mathrm{E}$ terhadap variabel $\mathrm{F}$ dapat dilihat pada kolom Besar Pengaruh (dalam \%) dan data detilnya dapat dilihat pada Tabel 7. Variabel yang harus menjadi perhatian adalah variabel yang berada di kuadran 2 karena kepentingannya tinggi, tapi kepuasannya rendah. Variabel yang berada di kuadran 2 akan masuk dalam perbaikan prioritas 1 dan variabel yang masuk dalam kuadran 3 akan masuk dalam perbaikan prioritas 2. Data detil dapat dilihat pada Tabel 8 dan Tabel 9. 
Tabel 4

Daftar Variabel dan Pertanyaan

\begin{tabular}{|c|c|}
\hline \multicolumn{2}{|r|}{ Pre-Purchase - Website Presentation (A1) } \\
\hline A1.1 & Kebaikan rancangan situs \\
\hline $\mathrm{A} 1.2$ & Kebaikan rancangan warna dari situs \\
\hline A1.3 & Kebaikan rancangan karakteristik situs \\
\hline A1.4 & Kebaikan dari rancangan struktur situs \\
\hline A1.5 & Teks \\
\hline A1.6 & Gambar \\
\hline A1.7 & Animasi \\
\hline \multicolumn{2}{|r|}{ Pre-Purchase - Access to Information (A2) } \\
\hline A2.1 & Kemudahan untuk memahami informasi dari produk \\
\hline A2.2 & Kelangkapan informasi dari produk \\
\hline A2.3 & Deskripsi tampilan luar produk \\
\hline A2.4 & Kehandalan dari informasi transaksi pembelian \\
\hline A2.5 & Pengaturan yang sesuai mengenai infromasi produk \\
\hline A2.6 & Kecepatan mengakses dan mendapatkan informasi \\
\hline A2.7 & Ketersediaan website setiap saat \\
\hline \multicolumn{2}{|r|}{ Pre-Purchase - Information Quality (A3) } \\
\hline A3.1 & Luas dan kedalaman informasi \\
\hline A3.2 & Memperbaharui informasi \\
\hline \multicolumn{2}{|r|}{ Pre-Purchase - Search Capabilities (A4) } \\
\hline A4.1 & Tingkat kesulitan \\
\hline $\mathrm{A} 4.2$ & Waktu yang diperlukan \\
\hline \multicolumn{2}{|r|}{ At-Purchase - Payment Methods (B1) } \\
\hline B1.1 & Auto-debet \\
\hline B1.2 & Informasi auto-debet \\
\hline \multicolumn{2}{|r|}{ At-Purchase - Privacy and Security (B2) } \\
\hline B2.1 & Personal Information \\
\hline \multicolumn{2}{|r|}{ At-Purchase - Dynamic Pricing (B3) } \\
\hline B3.1 & Mix product \\
\hline B3.2 & Keanekaragaman produk \\
\hline B3.3 & Harga \\
\hline \multicolumn{2}{|r|}{ At-Purchase - Promotion (B4) } \\
\hline B4.1 & $e$-mail \\
\hline B4.2 & Open House \\
\hline B4.3 & Kecepatan penyampaian informasi \\
\hline B4.4 & Akurasi informasi \\
\hline \multicolumn{2}{|r|}{ Post-Purchase - Problem Solving (C1) } \\
\hline C1.1 & Online manual \\
\hline $\mathrm{C} 1.2$ & FAQ \\
\hline $\mathrm{C} 1.3$ & Customer dapat mengajukan pertanyaan di website \\
\hline C1.4 & Fitur download \\
\hline $\mathrm{C} 1.5$ & Pemberian layanan yang cepat \\
\hline C1.6 & Helpful guidance \\
\hline $\mathrm{C} 1.7$ & Keakuratan informasi tentang produk / jasa \\
\hline C1.8 & Waktu yang diperlukan untuk menjawab customer problem \\
\hline \multicolumn{2}{|r|}{ Post-Purchase - Order Tracking (C2) } \\
\hline $\mathrm{C} 2.1$ & Histori Pembayaran \\
\hline $\mathrm{C} 2.2$ & Pemberitahuan status transaksi \\
\hline \multicolumn{2}{|r|}{ Post-Purchase - After Sale Service (C3) } \\
\hline C3.1 & Private message \\
\hline \multicolumn{2}{|r|}{ e-Trust - Need Fulfillment (D1) } \\
\hline D1.1 & Pengaksesan website oleh customer secara personal \\
\hline D1.2 & Layanan kepada customer secara personal \\
\hline \multicolumn{2}{|r|}{ e-Trust - Responsiveness (D2) } \\
\hline D2.1 & Respon yang cepat \\
\hline & e-Trust - Security (D3) \\
\hline D3.1 & Rahasia pribadi pelanggan \\
\hline & e-Trust - The Website's Technical Functional (D4) \\
\hline D4.1 & Signals technical reliability \\
\hline D4.2 & Penggunaan website \\
\hline & e-Satisfaction - Inertia (E1) \\
\hline E1.1 & Bookmark website \\
\hline & e-Satisfaction - Convenience Motivation (E2) \\
\hline E2.1 & Menjaga kerahasiaan data pelanggan \\
\hline E2.2 & Kemudahan untuk melakukan service online \\
\hline & e-Satisfaction -Perceived Value (E3) \\
\hline E3.1 & Kemudahan menggunakan website \\
\hline & e-Loyalty (F) \\
\hline F1 & Terus- menerus melakukan pembelian produk \\
\hline F2 & Melakukan pembelian yang banyak \\
\hline F3 & Bersedia membayar harga premium \\
\hline
\end{tabular}


Tabel 5

Hasil Uji Validitas dan Reliabilitas

Validitas

\begin{tabular}{|c|c|c|c|c|}
\hline \multirow{2}{*}{ Variabel - Sub Variabel } & \multicolumn{2}{|c|}{ Kepentingan } & \multicolumn{2}{|l|}{ Kepuasan } \\
\hline & Valid & Tidak Valid & Valid & Tidak Valid \\
\hline Pre-Purchase - Website Presentation (A1) & $\begin{array}{l}\text { A1.1, A1.2, A1.3, A1.4, } \\
\text { A1.5, A1.6, A1.7 }\end{array}$ & - & $\begin{array}{l}\mathrm{A} 1.1, \mathrm{~A} 1.2, \mathrm{~A} 1.3, \mathrm{Al} .4, \\
\mathrm{~A} 1.5, \mathrm{~A} 1.6, \mathrm{~A} 1.7\end{array}$ & - \\
\hline Pre-Purchase - Access to Information (A2) & $\begin{array}{l}\mathrm{A} 2.1, \mathrm{~A} 2.2, \mathrm{~A} 2.3, \mathrm{~A} 2.4, \\
\mathrm{~A} 2.5, \mathrm{~A} 2.6, \mathrm{~A} 2.7\end{array}$ & - & $\begin{array}{l}\mathrm{A} 2.1, \mathrm{~A} 2.2, \mathrm{~A} 2.3, \mathrm{~A} 2.4, \\
\mathrm{~A} 2.5, \mathrm{~A} 2.6, \mathrm{~A} 2.7\end{array}$ & - \\
\hline Pre-Purchase - Information Quality (A3) & $\mathrm{A} 3.1, \mathrm{~A} 3.2$ & - & $\mathrm{A} 3.1, \mathrm{~A} 3.2$ & - \\
\hline Pre-Purchase - Search Capabilities (A4) & A4.1, A4.2 & - & A4.1, A4.2 & - \\
\hline At-Purchase - Payment Methods (B1) & B1.1, B1.2 & - & B1.1, B1.2 & - \\
\hline At-Purchase - Privacy and Security (B2) & B2.1 & - & B2.1 & - \\
\hline At-Purchase - Dynamic Pricing (B3) & B3.1, B3.2, B3.3 & - & B3.1, B3.2, B3.3 & - \\
\hline At-Purchase - Promotion (B4) & B4.1, B4.2, B4.3, B4.4 & - & B4.1, B4.2, B4.3, B4.4 & - \\
\hline Post-Purchase - Problem Solving (Cl) & $\begin{array}{l}\text { C1.1, C1.2, C1.3, C1.4, } \\
\text { C1.5, C1.6, C1.7, C1.8 }\end{array}$ & - & $\begin{array}{l}\mathrm{Cl} 1.1, \mathrm{Cl} 1.2, \mathrm{Cl} 13, \mathrm{C} 1.4, \\
\mathrm{C} 1.5, \mathrm{C} 1.6, \mathrm{C} 1.7, \mathrm{C} 1.8\end{array}$ & - \\
\hline Post-Purchase - Order Tracking (C2) & $\mathrm{C} 2.1, \mathrm{C} 2.2$ & - & $\mathrm{C} 2.1, \mathrm{C} 2.2$ & - \\
\hline Post-Purchase - After Sale Service (C3) & $\mathrm{C} 3.1$ & - & $\mathrm{C} 3.1$ & - \\
\hline e-Trust - Need Fulfillment (D1) & D1.1, D1.2 & - & D1.1, D1.2 & - \\
\hline e-Trust - Responsiveness (D2) & D2.1 & - & D2.1 & - \\
\hline e-Trust - Security (D3) & D3.1 & - & D3.1 & - \\
\hline $\begin{array}{l}\text { e-Trust - The Website's Technical Functional } \\
\text { (D4) }\end{array}$ & D4.1, D4.2 & - & D4.1, D4.2 & - \\
\hline e-Satisfaction - Inertia (E1) & E1.1 & - & E1.1 & - \\
\hline e-Satisfaction - Convenience Motivation (E2) & E2.1, E2.2 & - & E2.1, E2.2 & - \\
\hline e-Satisfaction - Perceived Value (E3) & E3.1 & - & E3.1 & - \\
\hline e-Loyalty (F) & $\mathrm{F} 1, \mathrm{~F} 2, \mathrm{~F} 3$ & - & $\mathrm{F} 1, \mathrm{~F} 2, \mathrm{~F} 3$ & - \\
\hline
\end{tabular}

Tabel 6

Hasil Uji Korelasi

\begin{tabular}{|l|c|c|c|}
\hline \multicolumn{1}{|c|}{ Hipotesa } & $\begin{array}{c}\text { Pearson's } \\
\text { Correlation }\end{array}$ & Tidak ada hubungan $\left(\mathrm{H}_{0}\right)$ & Ada hubungan $\left(\mathrm{H}_{1}\right)$ \\
\hline Hipotesa 1 & 0,238 & Ditolak & Diterima \\
\hline Hipotesa 2 & 0,352 & Ditolak & Diterima \\
\hline Hipotesa 3 & 0,459 & Ditolak & Diterima \\
\hline Hipotesa 4 & 0,227 & Ditolak & Diterima \\
\hline Hipotesa 5 & 0,336 & Ditolak & Diterima \\
\hline Hipotesa 6 & 0,346 & Ditolak & Diterima \\
\hline Hipotesa 7 & 0,181 & Ditolak & Diterima \\
\hline Hipotesa 8 & 0,338 & Ditolak & Diterima \\
\hline Hipotesa 9 & 0,386 & Ditolak & Diterima \\
\hline Hipotesa 10 & 0,258 & Ditolak & Diterima \\
\hline Hipotesa 11 & 0,513 & Ditolak & Diterima \\
\hline Hipotesa 12 & 0,517 & Ditolak & Diterima \\
\hline Hipotesa 13 & 0,464 & Ditolak & Diterima \\
\hline Hipotesa 14 & 0,347 & Ditolak & Diterima \\
\hline
\end{tabular}

Tabel 7

Hasil Uji Regresi

\begin{tabular}{|l|c|c|c|c|c|}
\hline \multicolumn{1}{|c|}{ Hipotesa } & $\mathrm{R}$ & $\mathrm{R}$ Square & $\begin{array}{c}\text { Besar } \\
\text { Pengaruh }\end{array}$ & Tidak berpengaruh $\left(\mathrm{H}_{0}\right)$ & Berpengaruh $\left(\mathrm{H}_{1}\right)$ \\
\hline Hipotesa 15 & 0,414 & 0,172 & $17,2 \%$ & Ditolak & Diterima \\
\hline Hipotesa 16 & 0,460 & 0,211 & $21,1 \%$ & Ditolak & Diterima \\
\hline Hipotesa 17 & 0,505 & 0,255 & $25,5 \%$ & Ditolak & Diterima \\
\hline Hipotesa 18 & 0,279 & 0,078 & $7,8 \%$ & Ditolak & Diterima \\
\hline Hipotesa 19 & 0,385 & 0,148 & $14,8 \%$ & Ditolak & Diterima \\
\hline Hipotesa 20 & 0,454 & 0,206 & $20,6 \%$ & Ditolak & Diterima \\
\hline Hipotesa 21 & 0,329 & 0,108 & $10,8 \%$ & Ditolak & Diterima \\
\hline Hipotesa 22 & 0,425 & 0,181 & $18,1 \%$ & Ditolak & Diterima \\
\hline Hipotesa 23 & 0,429 & 0,184 & $18,4 \%$ & Ditolak & Diterima \\
\hline Hipotesa 24 & 0,329 & 0,108 & $10,8 \%$ & Ditolak & Diterima \\
\hline Hipotesa 25 & 0,541 & 0,293 & $29,3 \%$ & Ditolak & Diterima \\
\hline Hipotesa 26 & 0,538 & 0,289 & $28,9 \%$ & Ditolak & Diterima \\
\hline Hipotesa 27 & 0,469 & 0,220 & $22,0 \%$ & Ditolak & Diterima \\
\hline Hipotesa 28 & 0,385 & 0,148 & $14,8 \%$ & Ditolak & Diterima \\
\hline
\end{tabular}

eliabilitas

\begin{tabular}{|l|c|c|c|c|}
\hline \multicolumn{1}{|c|}{ Variabel - Sub Variabel } & \multicolumn{2}{|c|}{ Kepentingan } & \multicolumn{2}{c|}{ Kepuasan } \\
\cline { 2 - 6 } & Reliabel & $\begin{array}{c}\text { Tidak } \\
\text { Reliabel }\end{array}$ & Reliabel & $\begin{array}{c}\text { Tidak } \\
\text { Reliabel }\end{array}$ \\
\hline Pre-Purchase - Website Presentation (A1) & v & - & v & - \\
\hline Pre-Purchase - Access to Information (A2) & v & - & v & - \\
\hline Pre-Purchase - Information Quality (A3) & v & - & v & - \\
\hline Pre-Purchase - Search Capabilities (A4) & v & - & v & - \\
\hline At-Purchase - Payment Methods (B1) & v & - & v & - \\
\hline At-Purchase - Privacy and Security (B2) & v & - & v & - \\
\hline At-Purchase - Dynamic Pricing (B3) & v & - & v & - \\
\hline At-Purchase - Promotion (B4) & v & - & v & - \\
\hline Post-Purchase - Problem Solving (C1) & v & - & v & - \\
\hline Post-Purchase - Order Tracking (C2) & v & - & v & - \\
\hline Post-Purchase - After Sale Service (C3) & v & - & v & - \\
\hline e-Trust - Need Fulfillment (D1) & v & - & v & - \\
\hline e-Trust - Responsiveness (D2) & v & - & v & - \\
\hline e-Trust - Security (D3) & v & - & v & - \\
\hline $\begin{array}{l}\text { e-Trust - The Website's Technical Functional } \\
\text { (D4) }\end{array}$ & v & - & v & - \\
\hline e-Satisfaction - Inertia (E1) & v & - & v & - \\
\hline e-Satisfaction - Convenience Motivation (E2) & v & - & v & - \\
\hline e-Satisfaction - Perceived Value (E3) & v & - & v & - \\
\hline e-Loyalty (F) & v & - & v & - \\
\hline
\end{tabular}
e-Loyalty (F) 
Tabel 8

Hasil Gap Analisis

\begin{tabular}{|c|c|c|c|c|c|c|c|}
\hline \multirow{2}{*}{ Variabel } & \multicolumn{2}{|c|}{\begin{tabular}{|c|} 
Rata-rata \\
\end{tabular}} & \multirow{2}{*}{$\begin{array}{c}\text { Gap } \\
(\mathrm{Y}-\mathrm{X}) \\
\end{array}$} & \multicolumn{4}{|c|}{ Kuadran } \\
\hline & Kepentingan $(\mathrm{X})$ & Kepuasan (Y) & & 1 & 2 & 3 & \begin{tabular}{|l|}
4 \\
\end{tabular} \\
\hline Pre-Purchase (A) & 3.60 & 2.86 & -0.74 & $\mathrm{~A} 1.1, \mathrm{~A} 1.2, \mathrm{~A} 1.6, \mathrm{~A} 2.5$ & A4.2 & $\begin{array}{c}\mathrm{A} 1.3, \mathrm{~A} 1.7, \mathrm{~A} 2.1, \mathrm{~A} 2.3, \\
\mathrm{~A} 2.6, \mathrm{~A} 3.2, \mathrm{~A} 4.1\end{array}$ & $\begin{array}{l}\mathrm{A} 1.4, \mathrm{~A} 1.5, \mathrm{~A} 2.2, \mathrm{~A} 2.4, \\
\mathrm{~A} 2 . \mathrm{A} 3.1\end{array}$ \\
\hline At-Purchase (B) & 3.41 & 2.88 & -0.53 & $\mathrm{~B} 1.2, \mathrm{~B} 2.1$ & B1.1, B3.1, B4.3, B4.4 & B4.1 & $\mathrm{B} 3.2, \mathrm{~B} 3.3, \mathrm{~B} 4.2$ \\
\hline Post-Purchase (C) & 3.43 & 3.12 & -0.31 & $\mathrm{C} 1.1, \mathrm{C} 1.4, \mathrm{C} 1.8, \mathrm{C} 2.1$ & $\mathrm{C} 1.3, \mathrm{C} 1.7$ & $\mathrm{C} 1.5, \mathrm{C} 1.6, \mathrm{C} 3.1$ & $\mathrm{C} 1.2, \mathrm{C} 2.2$ \\
\hline $\mathrm{e}$-Trust (D) & 3.57 & 3.49 & -0.08 & D1.2, D3.1 & D1.1 & D2.1, D4.1 & $\mathrm{D} 4.2$ \\
\hline e-Satisfaction (E) & 3.42 & 3.03 & -0.39 & E3.1 & E2.2 & E1.1 & E2.1 \\
\hline
\end{tabular}

Tabel 9

Rangkuman Prioritas Perbaikan

\begin{tabular}{|c|c|c|c|}
\hline Variabel & Faktor-faktor yang sudah optimal & $\begin{array}{c}\text { Faktor-faktor yang segera ditingkatkan } \\
\text { pada prioritas } 1\end{array}$ & $\begin{array}{c}\text { Faktor-faktor yang segera ditingkatkan pada } \\
\text { prioritas } 2\end{array}$ \\
\hline \multirow{10}{*}{ Pre-Purchase (A) } & Kebaikan rancangan situs & \multirow{10}{*}{ Waktu yang diperlukan } & Kebaikan rancangan karakteristik situs \\
\hline & Kebaikan rancangan warna dari situs & & Animasi \\
\hline & \begin{tabular}{|l|} 
Gambar \\
\end{tabular} & & \multirow{2}{*}{$\begin{array}{l}\text { Kemudahan untuk memahami informasi dari } \\
\text { produk }\end{array}$} \\
\hline & Pengaturan yang sesuai mengenai infromasi produk & & \\
\hline & Kebaikan dari rancangan struktur situs & & \begin{tabular}{|l|} 
Deskripsi tampilan luar produk \\
\end{tabular} \\
\hline & Teks & & \multirow{2}{*}{$\begin{array}{l}\text { Kecepatan mengakses dan mendapatkan } \\
\text { informasi }\end{array}$} \\
\hline & Kelangkapan informasi dari produk & & \\
\hline & Kehandalan dari informasi transaksi pembelian & & Memperbaharui informasi \\
\hline & Ketersediaan website setiap saat & & \multirow{2}{*}{ Tingkat kesulitan } \\
\hline & Luas dan kedalaman informasi & & \\
\hline \multirow{5}{*}{ At-Purchase (B) } & Informasi auto-debet & Auto-debet & \multirow{5}{*}{ e-mail } \\
\hline & \begin{tabular}{|l|} 
Personal Information \\
\end{tabular} & Mix product & \\
\hline & Keanekaragaman produk & Kecenatan nenyamnaian informasi & \\
\hline & Harga & Kecepalan penyamparan mormas & \\
\hline & Open House & Akurasi informasi & \\
\hline \multirow{6}{*}{ Post-Purchase (C) } & Online manual & \multirow{3}{*}{$\begin{array}{l}\text { Customer dapat mengajukan pertanyaan } \\
\text { di website }\end{array}$} & \multirow{2}{*}{ Pemberian layanan yang cepat } \\
\hline & Fitur download & & \\
\hline & Waktu yang diperlukan untuk menjawab customer problem & & \multirow{2}{*}{ Helpful guidance } \\
\hline & Histori Pembayaran & \multirow{3}{*}{$\begin{array}{l}\text { Keakuratan informasi tentang produk / } \\
\text { jasa }\end{array}$} & \\
\hline & FAQ & & Private message \\
\hline & \begin{tabular}{|l|} 
Pemberitahuan status transaksi \\
\end{tabular} & & \\
\hline \multirow{3}{*}{ e-Trust (D) } & Layanan kepada customer secara personal & \multirow{3}{*}{$\begin{array}{l}\text { Pengaksesan website oleh customer } \\
\text { secara personal }\end{array}$} & Respon yang cepat \\
\hline & Rahasia pribadi pelanggan & & Signals technical reliability \\
\hline & Penggunaan website & & \\
\hline \multirow{2}{*}{ e-Satisfaction (E) } & Kemudahan menggunakan website & \multirow{2}{*}{$\begin{array}{l}\text { Kemudahan untuk melakukan service } \\
\text { online }\end{array}$} & \multirow{2}{*}{ Bookmark website } \\
\hline & Menjaga kerahasiaan data pelanggan & & \\
\hline
\end{tabular}

\section{PENUTUP}

Berdasarkan hasil pembahasan yang telah dibahas, penelitian ini dapat disimpulkan sebagai berikut: (1) dari hasil pengujian analisis korelasi dan regresi, maka dapat disimpulkan bahwa terdapat hubungan yang positif dan kuat antara Pre-Purchase, At-Purchase, Post-Purchase, e-Trust, eSatisfaction, dan e-Loyalty; (2) dari hasil analisis korelasi didapat seluruh nilai $r$ variabel lebih besar dari $r$ tabel (0.098), sehingga semua hipotesis $1\left(\mathrm{H}_{1}\right)$ diterima dan hipotesis nol $\left(\mathrm{H}_{0}\right)$ ditolak; (3) dari analisis regresi didapat seluruh semua hipotesis $1\left(\mathrm{H}_{1}\right)$ diterima dan hipotesis $0\left(\mathrm{H}_{0}\right)$ ditolak; (4) dari gap analisis, diketahui masih ada variabel yang perlu ditingkatkan pada prioritas 1 dan prioritas 2 .

Adapun rekomendasi yang diusulkan kepada BINUS University untuk prioritas pertama adalah: (1) meningkatkan kinerja search engine (www.binus.ac.id); (2) memberikan informasi yang lebih detil tentang jadwal autodebet pembayaran BP3 \& SKS (binusmaya.binus.ac.id); (3) meningkatkan keakuratan pemberian informasi mengenai program studi yang ditawarkan dan informasi ini harus lebih detil (binusmaya.binus.ac.id); (4) mempercepat penyampaian informasi berupa kurikulum dan materi pembelajaran di BINUS University sehingga mahasiswa dapat dengan mudah dan cepat memahami materi tersebut (binusmaya.binus.ac.id); (5) mempercepat penyampaian informasi berupa kurikulum dan materi pembelajaran di BINUS University sehingga mahasiswa dapat dengan mudah dan cepat memahami materi tersebut (binusmaya.binus.ac.id); (6) meningkatkan 
pengenalan fitur-fitur yang memungkinkan mahasiswa dapat mengajukan pertanyaan pada website sehingga mahasiswa lebih merasa terbantu (binusmaya.binus.ac.id); (7) lebih meningkatkan keakuratan informasi mengenai produk (program pembelajaran, seminar, dll) dan hal lainnya yang terdapat pada website (binusmaya.binus.ac.id); (8) meningkatkan fitur pada website yang memungkinkan user untuk mengakses website secara personal setiap saat. (www.binus.ac.id \& binusmaya.binus.ac.id); (9) perlu tambahan fitur-fitur dalam privasi data untuk setiap mahasiswa (id dan password) pada website. Misalnya: fitur yang digunakan apabila mahasiswa lupa password mereka (www.binus.ac.id \& binusmaya.binus.ac.id).

Sedangkan untuk prioritas kedua adalah: (1) pemilihan font pada website yang perlu diperhatikan agar user tidak cepat bosan apabila mengunjungi website (www.binus.ac.id); (2) penggunaan animasi pada website untuk membantu pengunjung memahami isi website dan menarik pengunjung baru (www.binus.ac.id); (3) perlunya meningkatkan penjelasan informasi yang lebih detail mengenai program studi yang terdapat pada website (www.binus.ac.id); (4) perlunya meningkatkan akses pencarian informasi pada website (www.binus.ac.id); (5) secara rutin melakukan update pada website (www.binus.ac.id); (6) adanya fitur search engine yang memudahkan user dalam mencari informasi pada website (www.binus.ac.id); (7) penggunaan email sebagai sarana penyebaran informasi produk (program studi) harus lebih ditingkatkan (binusmaya.binus.ac.id); (8) meningkatkan kecepatan dalam pemberian layanan kepada customer (binusmaya.binus.ac.id); (9) meningkatkan fitur panduan layanan pada website yang memudahkan customer (binusmaya.binus.ac.id); (10) meningkatkan pemberian respon yang cepat dan tepat terhadap feedback yang telah diberikan oleh mahasiswa (www.binus.ac.id \& binusmaya.binus.ac.id); (11) meningkatkan fitur-fitur pada website sehingga memudahkan customer untuk melakukan service online (www.binus.ac.id \& binusmaya.binus.ac.id).

\section{DAFTAR PUSTAKA}

Alhaiou, T., Ali, M. \& Irani, Z.. (2009). The relationship between E-CRM implementation and eloyalty at different adoption stages of transaction cyle: a conceptual framework and hypothesis. European and Mediterranean Conference on Information Systems.

Brandt, D.R. (2000). An "outside-in" approach to determining customer-driven priorities for improvement and innovation. White Paper Series, 2.

Chaffey, Dafe. (2009). E-Business and E-Commerce Management $\left(4^{\text {th }}\right.$ edition). New York: Prentice Hall.

Greenberg, Paul. (2010). CRM Customer Relationship Management, Social CRM Strategies, Tools, and Techniques for Engaging Your Customers, at the Speed of Light ( $4^{\text {th }}$ edition). New York: McGraw-Hill.

Hays, W. L. (1976). Quantification in Psychology. New Delhi: Prentice Hall.

Latu, T.M., \& Everett, A. M. (2000). Review of Satisfaction Research and Measurement Approaches. Wellington, New Zealand: Departement of Conservation.

Martinez, C. L. (2003) Evaluation Report: Tools Cluster Networking Meeting \#1. Arizona: CenterPoint Institute. 
Meyliana, Wibowo, D., Suryanaga, A. \& Sutanto. L. H. (2011). Analisis Kepuasan Mahasiswa terhadap Implementasi e-CRM di BINUS University (Studi Kasus Jurusan Sistem Informasi). Skripsi tidak diterbitkan. Universitas Bina Nusantara, Jakarta.

Sugiyono. (2008). Metode Penelitian Bisnis. Bandung: Alfabeta. 